\title{
SAREKAT ISLAM (SI) GERAKAN PEMBARUAN POLITIK ISLAM
}

\author{
Ismail Usman \\ Institut Agama Islam Negeri(IAIN) Manado \\ pai@iain-manado.ac.id
}

\begin{abstract}
The birth of a politically oriented Sarekat Islam with the forerunner of business oriented Islamic Trade Sarekat was inseparable from the strong motivation to implement Islamic teachings in various aspects. Not only limited to worship rituals, but also need to be translated into the midst of other aspects, especially at that time the condition of the Indonesian people was under Dutch colonialism, so Islamic political movements were a mystery and focus. Using Islamic labels in organizations that allow positive responses everywhere to participate in this organization. In this paper the author wants to know what the Sarekat Islam has been doing in carrying out political relations and anything that contributes to the movement of Indonesian nationalism with Islam as a basic effort and whatever efforts are needed in upholding these noble ideals.
\end{abstract}

Keywords: Politics, Islam, Islamic Trade Law, Nationalism.

Abstrak. Lahirnya Sarekat Islam yang berorientasi politik dengan cikal bakal dari Sarekat Dagang Islam yang berorientasi bisnis tampaknya tidak lepas dari motivasi kuat untuk mengimplemantasikan ajaran-ajaran Islam dalam berbagai aspeknya. Bukan saja terbatas pada ibadah ritual, tapi juga perlu dijabarkan ke tengah-tengah masyarakat aspek-aspek lain, lebih-lebih pada waktu itu kondisi bangsa Indonesia sedang berada di bawah tekanan kolonial Belanda, maka kehadiran gerakan politik Islam merupakan tuntutan dan keharusan. Menggunakan label Islam dalam organisasi politik ini mungkin dimaksudkan untuk menarik respons masyarakat muslim di mana saja untuk ikut serta berpartisipasi dalam organisasi ini. Dalam makalah ini penulis ingin membahas sejauh mana kiprah Sarekat Islam dalam melakukan pembaruan politik dan apa sumbangsinya terhadap gerakan nasionalisme Indonesia dengan Islam sebagai ajaran dasar serta kendala-kendala apa yang dihadapi dalam menegakkan cita-cita luhur ini.

Keywords: Politik, Islam, Sarekat Dagang Islam, Nasionalisme 


\section{Pendahuluan}

Gerakan suatu organisasi seringkali timbul akibat adanya tekanan, ketidak adilan dan perlakuan diskriminasi dari pihak lain. Gerakan ini menyusun kekuatan untuk merekrut semua potensi dan menandingi kekuatan luar, sehingga eksistensinya diperhitungkan. Demikian halnya kehadiran gerakan Sarekat Islam salah satu model pembaharuan Politik, dilatar belakangi oleh sikap non pribumi Cina yang menguasai dunia bisnis dan mendiskreditkan penduduk asli. Ditambah lagi dengan sikap kaum bangsawan yang melakukan penetrasi kepada masyarakat Indonesia, terutama yang berdomisili di Solo, tempat lahirnya organisasi politik ini.

Sebagaimana diyakini bahwa Islam adalah agama universal yang mengatur semua aspek kehidupan manusia.Lahirnya Sarekat Islam yang berorientasi politik dengan cikal bakal dari Sarekat Dagang Islam yang berorientasi bisnis tampaknya tidak lepas dari motivasi kuat untuk mengimplemantasikan ajaran-ajaran Islam dalam berbagai aspeknya. Bukan saja terbatas pada ibadah ritual, tapi juga perlu dijabarkan ke tengah- tengah masyarakat aspek-aspek lain, lebih-lebih pada waktu itu kondisi bangsa Indonesia sedang berada di bawah tekanan kolonial Belanda, maka kehadiran gerakan politik Islam merupakan tuntutan dan keharusan. Menggunakan label Islam dalam organisasi politik ini mungkin dimaksudkan untuk menarik respons masyarakat muslim di mana saja untuk ikut serta berpartisipasi dalam organisasi ini.

Dalam makalah ini penulis ingin membahas sejauh mana kiprah Sarekat Islam dalam melakukan pembaruan politik dan apa sumbangsinya terhadap gerakan nasionalisme Indonesia dengan Islam sebagai ajaran dasar serta kendalakendala apa yang dihadapi dalam menegakkan cita-cita luhur ini.

\section{Latar Belakang Berdirinya Sarekat Islam}

Sarekat Islam adalah satu di antara organisasi politik Indonesia abad ke 20 yang paling menonjol Ia sejak semula adalah gerakan politik. SI adalah transformasi dari Sarekat Dagang Islam (SDI) yang didirikan di Solo pada 11 Nopember 1911 oleh H. Samanhudi, seorang pedagang muslim kaya di Surakarta, Jawa Tengah. SDI mula- mula diarahkan melawan kegiatan Cina yang menguasai dunia perdagangan dengan mengorbankan pribumi; Di sisi lain adalah perlawanan tidak langsung ditujukan kepada Belanda yang memberikan prioritas dan perlindungan kepada usahawan Cina yang agresif dalam perdagangan dan industri. Pada 1912 SDI menjadi SI dan mendapatkan pemimpin organisator baru yang kompeten, $\mathrm{H}$ O S Tjokroaminoto (1883-1934). ${ }^{1}$

Perubahan SDI menjadi SI punya tujuan politis dan strategis, betapa tidak karena diharapkan organisasi ini bukan saja berkiprah dalam bidang ekonomi, akan tetapi diperluas wawasannya dalam bidang politik Hal ini penting karena kondisi pada waktu itu menuntut berdirinya partai Islam sebagai wadah aspirasi ummat Islam yang dapat disalurkan kepada Pemerintah Hindia Belanda Sebagai konsekwensi logis tentunya diperlukan seorang figur pemimpin yang memiliki mental berani untuk dapat menjembatani aspiasi tersebut. Pilihan figur leadership kepada H.O.S Tjokroaminoto adalah sangat tepat, karena beliau dikenal sebagai tokoh radikal.

SI lahir sebagai sikap perlawanan dari unsur non pribumi Cina yang seringkah mengorbankan pribumi dalam dunia bisnis.Jadi dikotomi antara pribumi dan non pribumi pada dasarnya sudah

1 Ahmad Syafii Maarif,Islam dan Masalah Kenegaraan, (Jakarta: PT. Pustaka LP3S, Cetakan ketiga, 1996), h. 79 
muncul sejak dulu dan ini ditunjukkan oleh ambisi kuat pihak non pribumi untuk menguasai lapangan usaha dengan mendiskreditkan pihak pribumi.

Oleh karena itu minimal ada dua faktor penyebab berdirinya organisasi Sarekat islam ini, pertama, kompetisi yang meningkat dalam bidang perdagangan batik terutama dengan Cina,dan sikap superioritas orang-orang Cina terhadap orang-orang Indonesia sehubungan dengan berhasilnya revolusi Cina pada tahun 1911. Kedua, karena mendapat tekanan dari kalangan bangsawan terhadap masyarakat Indonesia di Solo.Sarekat Dagang Islam dimaksudkan menjadi benteng bagi orang-orang Indonesia yang umumnya terdiri dari pedagang- pedagang batik di Solo terhadap orang-orang Cina dan para bangsawan. ${ }^{2}$

\section{Beberapa Tokoh SI}

Perlu disinggung secara singkat tokoh-tokoh Sarekat islam yang paling menonjol dan banyak memberikan pemikiran dan gagasan serta melakukan perubahan dalam upaya sosialisasi organisasi ini.

\section{H. Samanhudi}

H. Samanhudi pendiri Sarekat Islam lahir didesa Sondokoro karanganyar, Solo sebagai seorang anak pedagang batik yang bernama H Muhammad Zen. Keluarga ini pindah ke Lawiyan Solo, ketika Wifjowikoro (nama kecil Samanhudi) berumur dua tahun. Setelah menyelesaikan pendidikan rendahnya di sekolah kelas dua, Samanhudi membantu ayahnya dalam berdagang batik sampai ia dapat berdiri sendiri dengan membuka perusahaan batik pada tahun 1888. Ia berhasil dalam bidang usaha ini sehingga dapat mengembangkan sayapnya dengan membuka cabang-cabang perusahaan di berbagai kota di Jawa seperti di Surabaya,

2Deliar Noer, Gerakan Moderen Islam, Jakarta: LP3ES, 1995). h. 116
Banyuwangi, Tulungangung, Bandung dan Parakan Pada tahun 1904 ia pergi ke Mekkah untuk menunaikan ibadah haji dan kembali pada tahun berikutnya. ${ }^{3}$

Pada masa itu Samanhudi mempunyai minat yang besar untuk mendirikan berbagai organisasi yang bersifat sosial, umpamanya organisasiorganisasi yang memberikan bantuan dalam upacara perkawinan, keperluan selamatan, dan keperluan penyelenggaraan kematian. Walaupun pengetahuannya dalam Islam terbatas.,ia sangat beriman Barangkali dapat dikatakan bahwa ia adalah seorang muslim yang tipikal pada masanya, yang meyakini islam sebagai agamanya sendiri dan membedakannya dari orang asing ataupun orang non muslim la sendiri merasa bahwa gelar kiyainya yang sering dihubungkan dengan namanya adalah kurang pada tempatnya. ${ }^{4}$

\section{H.O.S Tjokroaminoto}

. H.O S.Tjokroaminoto seorang tokoh penting yang memasuki Sarekat Islam pada tahun-tahun pertama organisasi ini berdiri dan yang kemudian menjadi sekan- seakan satu-satunya pemimpin datam organisasi ini serta berhasi! mempertahankan kedudukan kepemimpinan ini sampai meningga! pada tahun 1934. Tjokroaminoto ditahirkan di Bakur, Madiun Jawa Timur pada tangga 16 Agustus 1882, ia berasa) dari keluarga bangsawan yang taat beragama. Setelah menyelesaikan sekolah administrasi pemerintahan di Magelang, ia menjadi pegawai pemerintah sebagai jurutulis pada patih. Ngawi selama tiga tahun la kemudian menjadi patih tetapi mengerjakan pekerjaan ini untuk pindah ke Surabaya, tempat ia bekerja pada sebuah p perusahaan Belanda la mengikuti kursus-kursus malam dalam soal teknik mesin untuk tiga tahun

\footnotetext{
3. Deliar Noer, Gerakan Modem Islam, .h. 20

${ }^{4}$ Ibid, h. 120
} 
lamanya 1907 -1910. Dan bekerja sebagai pegawai pada sebuah pabrik gula di luar kota Surabaya pada tahun 1991 - 1912. Ketika didatangi delegasi dari Sarekat Islam Solo untuk bergabung pada organisasi ini, Tjokroaminoto telah terkenal dengan sikapnya yang radikal dengan menentang kebiasaan-kebiasaan yang memalukan bagi rakyat banyak, la dikena! sebagai seorang yang menganggap dirinya sama sederajat dengan pihak manapun juga, apakah dengan seorang Belanda ataupun dengan seorang pejabat pemerintah Dan iapun berkeinginan sekali untuk melihat sikap ini juga dimiliki oleh kawan sebangsanya terutama di dalam berhubungan dengan orang-orang asing, la memang disebut sebagai orang Gatotkoco Sarekat Islam.

Tjokroaminoto bergabung dengan SI di Surabaya pada bulan Mei 1912 atas ajakan dari pendirinya Haji Samanhudi yang memang mencari orsang-orang yang teiah pemah mendapat pendidikan iebih baik dan lebih berpengalaman untuk memperkuat organisasi. Tjokroaminoto melakukan pembaharuan dengan menyusun sebuah anggaran dasar baru untuk organisasi itu bagi seluruh rakyat Indonesia dan meminta pengakuan dari pemerintah untuk menghindarkan diri dari apa yang disebutkan "pengawasan preventif dan represif secara administratif'. Hal ini dilakukan pasca pencabutan dari pembekuan organisasi tersebut dengan catatan agar Anggaran Dasamya diubah

\section{Raden Mas Tirtoadisutjo}

Periode pertama dari Sarekat islam ditandai oleh perhatian terhadap masalahmasalah organisasi, termasuk di dalamnya usaha mencari pimpinan, penyusunan Anggaran Dasar dan hubungan antara organisasi pusat dengan organisasi daerah. Penyelesaian yang cukup berhasil dalam ketiga masalah ini mencapai puncaknya pada periode 1916 sampai 1921 Anggaran Dasar pertama bertanggal ll Nopember 1911 dirumuskan oleh oleh Raden Mas Tirtoadisutjo yang pada masa itu termasuk salah seorang dari sejumlah orang-orang Indonesia yang memperoleh pendidikan lumayan. Ia adalah lulusan dari sekolah administrasi pemerintah Belanda bemama OSVIA Ia aktif dalam pers antara lain menerbitkan majalah Medan Prijaji di Bogor. Ia juga. mendirikan sebuah organisasi dagang bernama Sarekat Dagang Islamiyah di Bogor tahun 1911. 5

\section{Raden Gunawan}

Seorang kawan karib Samanhudi di Jawa Barat yang mempropagandakan Sarekat islam di daerah ini dan juga di Sumatera Selatan bernama Raden Gunawan, dilahirkan di Ngawi, Jawa Timur pada tanggai i2Pebruari 1880. Gunawan adalah anak seorang pegawai pemerintah la memperoleh pendidikan agama secara tradisi, tetapi tidak mendalam dan juga belajar pada sekolah yang didirikan pemerintahpada tingkat rendah serta pada sekolah administrasi pemerintahan di probolinggo pada tahun 1890-an. Pada tahun 1899 ia menjadi pegawai dengan bekerja pada kantor pemerintah yang memindahkannya dari suatu tempat ke tempat lain di Pulau Jawa sampai pada tahun 1907, ketika ia meninggalkan kepegawainnya itu. Pada masa itu ia sangat menyadari akan ketidak adilan yang dirasakan seorang anak,ia melihat ayahnya ditahan untuk sepuluh hari lamanya, hanya karena ia meninggalkan pekerjaannya untuk hadir pada penguburan ibunya. Menjelang akhir tahun 1890-an, Gunawan diberhentikan dari kantor Asisten Residen Pacitan di mana ia bekerja tanpa bayaran, sematamata oleh karena ia bertikai dengan seorang Indo yang memperlihatkan sikap yang pada umumnya sangat menghina bangsa Indonesia. Gunawan tidak dapat bertoleransi terhadap sikap ini dan tidak dapat membiarkan begitu saja dalam

${ }^{5}$ Ibid, h. 116 
kehidupan sehari-hari kedudukan rendah dari bangsanya.

\section{Haji Agus Salim.}

Tokoh lain yang periu diperhitungkan yang bergabung ke sarekat islam dalamperiode pertama ini ialah H. Agus salim. Ia berhubungan dengan organisasi ini pada tahun 1915 sebagai seorang anggota seksi politik dan kepolisian. Ia tidak popuier pada periode pertama, tetapi ia berhasil mencapai suatu kedudukan kepemimpinan dalam periodeperiode berikutnya, terutama dalam membentuk dan memberi isi pada Sarekat Islam dengan warna Islamnya.

Dilahirkan di Kota Gedang Bukittinggi pada 8 Oktober 1884 sebagai seorang anak dari seorang pejabat pemerintah yang yang juga berasal dari kalangan bangsawan dan agama.Salim menyelesaikan pelajaran sekolah menengahnya (HBS) di Jakarta dan kemudian bekerja pada konsulat Belanda di Jeddah pada tahun 1906 sampai 1909. Di sini ia memperoleh kesempatan untuk memperdalam pengetahuannya tentang Islam.

Setelah kembali ke Jakarta ia bekerja pada departemen Pekerjaan Umum 1911-1912 kemudian kembali ke kampung halamannya di Minangkabau untuk mendirikan sebuah sekolah dasar (HIS) sampai tahun 1915. Seorang anak muda yang sangat cekatan di antara teman-teman semasanya.Ia pada waktu itu belum dapat dengan tegas memilih organisasi yang akan dimasuki. Malah keraguan ini masih juga terdapat ketika ia baru memasuki Sarekat Islam. Demikianlah ia menjadi anggota dari satu organisasi ke organisasi lain. Perkumpulan teosofi, NIVB (Nederlands Indische Vrijzinnigen Bond), dan Indoische Social Democratische Partai (ISDP) ${ }^{6}$.

\section{Tujuan Pendirian SI}

Jika dicermati dalam pendirian Sarekat Islam sebagai basis gerakan politik 7. Ummat Islam di zamannya, dapatlah ditemukan beberapa pemikiran yang menjadi tujuan pendirian dari organisasi politik ini.Tujuan itu diformulasikan menjadi dua bagian jangka pendek dan jangka panjang.

\section{Jangka Pendek}

Tujuan pendirian SI tertuang dalam anggaran Dasar organisasi tersebut,yang pada intinya ingin membina kerjasama antar sesama anggota, tolong menolong, menciptakan kerukunan antara sesama muslim, menciptakan usaha yang halal yang tidak bertentangan dengan aturan pemeimtah baik opusat maupun daerah, menciptakan kehidupan makmur, sejahtera kepada rakyat demi kebesaran negeri ini. Tujuan ini disebutkan dalam AD SI sebagai berikut:

Aku berikhar supaya angota-angotanya satu sama lain bergaul seperti saudara dan supaya timbullah kerukunan dan tolong menolong satu sama lain anyar sekalian kaum muslimin dan lagi dengan segala daya upaya yang halal dan tidak menyalahi wete-wet government, berikthiar mengangkat derajat rakyat agar menimbulkan kemakmuran.kesejatraan dan kebesaranya negeri. ${ }^{8}$

\section{Jangka Panjang}

Adapun tujuan jangka panjang SI adaiah islamisasi yang semakin mantap bagi masyarakat Indonesia.Untuk meraih tujuan jangka panjang ini maka kemerdekaan tanah air merupakan sesatu yang mutiak. Tjokroaminoto sering menegaskan masalah ini, dan pada tahun 1931 ia menulis :

"...... tak boleh tidak kita kaum muslimin mesti mempunyai kemerdekaan umat atau kemerdekaan berbangsa ( national virjheid) dan mesti berkuasa atas negeri tumpah dara kita sendri.

\section{9. Ibid.h. 123}

${ }^{8}$ Ibid,h.117 


\section{Pembekuan SI}

Akan tetapi setelah Sarekat Dagang ini berkembang cepat ke daerah-daerah tain di jawa dan seteiah kegiatan-kegiatan para anggotanya di Solo meningkat tanpa dapat diawasi oleh penguasa setempat. Residen Surakarta segera ${ }^{9}$ membekukan organisasi politik ini.Perkelahian terus menerus terjadi dengan Gotongan Cina.Sebuah pemogokan ditancarkan oieh pekerja-pekerja di perkebunan Krapyak di Mangkunegara pada permulaan bulan agustus 1912.Kedua macam kerusuhan ini menurut pihak penguasa disebabkan oleh Sarekat Islam. Kemudian pembekuan tadi dicabut kembali pada tanggal 26 Agustus 1912 dengan syarat agar Anggaran Dasarnya diubah sedemikian rupa, sehingga ia hanya terbatas pada daerah Surakarta saja.

\section{Periode Awal 1911-1916}

Selama periode awal, SI mendapat sambutan positif dari rakyat Indonesia.Hanya dalam tempo singkat, SI telah berkembang dengan cepatnya.Berbeda dengan Budi Utomo yang membatasi keanggotaannya bagi priyayi Jawa dan Madura, SI terbuka untuk setiap orang Indonesia yang memandang latar belakang sosioetnis mereka. Ekspansi Si tidak hanya menembus sektor urban masyarakat Indonesia, tapi juga kaum tani di pedesaan memberikan sokongan kepadanya 10. Kebijakan SI sebagai organisiasi massa terbuka diharapkan dapat merekrut partisipan sebanyak-banyaknya, karena keberhasilan partai politik ditentukan oleh jumlah massa yang besar. Di samping memiliki program jelas yang dapat memberikan kemakmuran dan kesejahteraan untuk orang banyak. Akan tetapi massa besar jika tidak diberdayakan secara maksimal, inipun pada akhimya menjadi bumerang dan

\footnotetext{
${ }^{9}$ H. Ahmad Syafii maarif Op cit. h. 80

${ }^{10}$ Deliar Noer, Gerakan Modem Islam.. h. 117.
}

malapetaka bagi partai tersebut. Lebihlebih jika masuk kaum munafik yang bermuka dua, bersikap ganda. Jika masuk infiltrasi luar yang berseberangan ideologi dan pemikiran, tidak mustahil partai itu akan digergoti dari dalam.

\section{Periode Kedua 1916 -1921}

Pada periode ini struktur organisasi tampaknya cukup stabii Sarekat Islam memberikan perhatian kepada berbagai masalah baik politik maupun agama. Sifat politiknya tercermin dengan jelas pada nama dari kongres-kongres tahunannya. Pada periode pertama pertemuanpertemuan tahunan disebutkan kongres saja, sedangkan pada periode kedua kongres-kongres tersebut disebutkan kongres nasional. Hal ini tidak sekedar mencerminkan bahwa partai tersebut telah tersebar di seluruh persada tanah air dan bahwa kongres-kongres itu diikuti oleh utusan-utusan dari segenap daerah, tetapi juga mencerminkan suatu usaha yang sadar dari pemimpin-pemimpinnya untuk menyebarkan dan menegakkan cita-cita nasionalisme dengan Islam sebagai ajaran dasar dari pemikiran tersebut.

\section{Sifat Politik dan Program Kerja}

Sifat politik dari organisasi ini dirumuskan dalam "Keterangan Pokok" (Asas) dan Program Keija yang disetujui oleh kongres nasional kedua pada tahun 1917 Keterangan Pokok ini mengemukakan kepercayaan Central Sarekat Islam bahwa agama Islam itu membuka rasa pikiran perihal persamaan derajat manusia sambil menjunjung tinggi kepada kuasa negeri. Sedangkan Program kerja dibagi atas delapan bagian; Politik, Pendidikan, Agama, Keadilan, Agraria dan Pertanian, Keuangan dan Perpajakan, Perlindungan Hukum serta Nasionalisasi industri-industri penting.

Dalam bidang politik Sarekat Islam menuntut berdirinya dewan-dewan 
daerah, perluasan hak-hak Volksraad (Dewan Rakyat) dengan tujuan untuk mentransformasikannya menjadi suatu tembaga perwakiian yang sesungguhnya untuk keperluan legislatif.Dalam bidang pendidikan partai menuntut penghapusan peraturan yang mendiskrimanasikan penerimaan murid di sekoiah-sekoiah, Partai juga menuntut wajib belajar untuk semua penduduk sampai berumur 15 tahun, perbaikan sarana pendidikan daiam semua tingkat.Daiam bidang agama Partai menuntut dihapuskannya segaia macam undang-undang dan peraturan yang menghambat tersebarnya Islam, pembayaran gaji bagi Kiyai dan penghuiu, subsidi bagi lembaga-lembaga pendidikan.

Islam dan pengakuan hari-hari besar Islam. Dalam Masalah keadilan, Sarekat Islam menuntut pemisahan antara kekuasaan yudikatif dan eksekutif perlu dibangun suatu hukum yang sama untuk menegakkan hak-hak yang sama di antara golongan penduduk negeri, menuntut perlindungan hukum bagi penduduk miskin. Dalam bidang agraria dan pertanian perlu diadakan perbaikan dengan menghapuskan milik tuan tanah dan dengan mengadakan ekspansi serta perbaikan irigasi. .

\section{Timbul Perpecahan di Tubuh SI}

Virus perpecahan ini mulai menyebar ketika beberapa tokoh SI yang memiliki ideologi komunis masuk ke dalam tubuh Sarekat Islam.Mereka adalah hasil didikan H.J.F.Sneevtiet salah seorang Marxis Belanda yang datang ke Nusantara dengan maksud menyebarkan paham komunis. Tokoh SI yang berhaluan komunis itu antara lain Semaun dari cabang SI Semarang, Atimin Prawirodirdjo ${ }^{11}$ dan Darsono. Timbul pertikaian ketika terjadi silang pendapat masalah keikutsertaan SI pada Volksraad (Dewan Rakyat), versi Abdul Moeis menghendaki SI untuk terlibat dalam Dewan rakyat itu sementara Semaun berpendapat bahwa Volksraad hanyalah suatu pertunjukan kosong, suatu akal dari kaum kapitalis untuk mengelabui mata rakyat jelata untuk memperoeh untung lebih banyak.Tetapi Sarekat Islam lebih menyetujui pendapat Moeis dan memutuskan untuk berpartisipasi dalam Volksraad.

\section{Perbedaan Semakin Meruncing}

Persoalan Volksraad akhirnya menghangat kembali dan kali ini pihakpihak yang semua pro mulai menggugat keberadaan SI di dalam Dewan rakyat itu.Sosrokardono sekretaris central SI menuntut agar Tjokroaminoto dan Moeis 12 meninggatkan Dewan rakyat tersebut dengan alasan bahwa keterhbatan mereka di dalam lembaga itu menyebabkan terpecahnya partai. Sedangkan ketompok sebaliknya, ia mempertahankan partisipasi partai di dalam Dewan yang menurut pendapatnya merupakan forum latihan tentang masalah-masalah politik. Namun pada akhirnya Salim pun berubah dan berbalik haluan serta mencap Dewan rakyat sebagai komidi omong. ${ }^{13}$

Perpecahan semakin meruncing antara pihak Moeis dan pihak Semaun. Pihak Semaun malahan mengancam untuk mendirikan Central Sarekat Islam lain, bila mereka kalah dalam pertarungan ini. Sarekat Islam Bogor mulanya mengusulkan agar kedua pihak berkompromi, tetapi akhirnya Sarekat Islam Bogor ini menyokong pihak Moeis, setelah mengetahui bahwa separuh dari anggota pengurus central Sarekat Islam akan mengundurkan diri bila Indie Weerbaar ditolak. Ahmad Syafii Maarif menegaskan bahwa SI harus menghadapi rintangan lain yang lebih serius dan ideologis sifatnya. Rintangan adalah tindakan Gubemur Jenderal Idenburg

11Ibid. h. 29

12Ibid, h. 131

\footnotetext{
${ }^{13}$ Ahmad Syafii Maarif. Op Cit, h. 83
} 
yang telah memberikan peluang kepada ideologi baru yang radikal, yaitu Marxisme untuk melakukan infiltrasi terhadap SI melalui cabang-cabang SI di daerahdaerah. ${ }^{14}$

Oleha karena itu Abdul Moeis menulis bahwa Sneevliet sengaja dikirim ke Indonesia untuk memecah gerakan rakyat dan karena ia berbahaya besar bagi kami dan tanah kami. Pemimpin Sarekat Islam ini menuntut supaya Pemerintah membuang Sneevliet dari Indonesia Salim dan Sosrokardono yang terakhir adalah sekretaris dari Central Sarekat Islam mempunyai pandangan sama. Salim melihat kegiatan-kegiatan ISDV juga sebagai suatu usaha untuk memindahkan pertikaian-pertikaian yang terjadi di Eropa ke Indonesia ${ }^{15}$

\section{Pembersihan Komunis dari SI}

Sarekat Islam tampaknya semakin kacau dan pecah setefah tetjadi infiltrasi ketompok yang berhaluan Marxisme oleh karena itu perlu menyingkirkan orangorang kiri itu dari dalam tubuh partai agar partai ini menjadi solid dan kuat kembali.Sikap ini dipelopori oteh Salim, Moeis dan juga Sutjopranoto.Karena hal ini persoalan ideologi dan itu sangat prinsipil.Oleh sebab itu mereka memperjuangkan pengeluaran orangorang komunis dari lingkungan partai.Salim bertindak sebagai juru bicara dari kalangan pemimpin yang anti Komunis.Ia mengemukakan bahwa tindakan disiplin haruslah juga diambil terhadap PKI karena hal ini sangat perlu untuk menegakkan dasar partai itu sendiri yaitu Islam. Penetrasi dasar-dasar bukan Islam yang selama ini masuk dalam lingkungan partai, telah melemahkan partai.

\footnotetext{
${ }^{14}$ Ibid. h. 137

15 Ibid, h. 138
}

\section{Propaganda Pembelaan Semaun}

Semaun sebagai kubu komunis melakukan advokasi terhadap PKI dengan mengemukakan bahwa partai ini mampu mempersatukan rakyat, baik muslim maupun bukan. Partai ini didirikan untuk kepentingan umum dari rakyat seluruhnya. Ia menunjukkan pada usahausaha orang komunis yang tela mengubah Sarekat Islam dari partai kapitalis menjadi partai untuk rakyat Ia mengemukakan pendapat bahwa pemikirasn-pemikiran PKI dan Sarekat Islam bukanlah tidak bersesuaian. Oleh sebab itu Semaun menyarankan dengan sangat agar pikiran untuk mendisiplin PKI dihilangkan saja. ${ }^{16}$

Usaha pembelaan Semaun ini tidak berhasil. Kongres tahun 1921 di Surabaya yang diadakan ketika Tjokroaminoto masih berada di dalam tahanan, menyokong kubu Salim -Moeis dengan 23 lawan 7 suara. Dengan demikian orangorang Komunis dikeluarkan dari Sarekat Islam.Mereka yang menentang SalimMoeis ialah Sarekat Islam dari Semarang, Solo, Salatiga, Sukabumi, dan Bandung. ${ }^{17}$

\section{SI Semakin Lemah}

Komunisme

memang telah menggoncangkan tubuh partai Sarekat Islam yang telah mengambil Islam sebagai dasar bagi kesatuan mereka Dasar ini telah memberikan para pengikut Sarekat Islam, terutama mereka yang kurang merasa terikat pada agama, suatu alternatif untuk memilih kebijaksanaan yang diturut. Loyalitas anggota-anggota ini kepada partai menjadi menipis dan oleh sebab itu kesatuan di dalam Sarekat Islam menjadi lemah.Malahan sebelum perpecahan di dalam Sarekat Islam pada tahun 1921 dapat dikatakan bahwa partai memang telah terbelah dua, terdiri dari mereka yang pro komunis dan yang anto komunis. ${ }^{18}$

\footnotetext{
16 Lbid, h. 140

17 Lbid, h. 140

18 Ibid, h. 141
} 


\section{Kesimpulan}

Sarekat Islam yang lahir dari induk semangnya Sarekat Dagang Islam adalah gerakan politik abad 20 untuk mengkounter sikap tidak bersehabat dari non pribumi Cina yang mendapat dukungan kolonial Belanda untuk mengobok-obok penduduk asli bangsa Indonesia. Didirikan di Solo tanggal 1 Nopember 1911 oleh H. Samanhudi, seorang padagang muslim kaya di Surakarta. Memilih angka 11 untuk tanggal, bulan dan tahun pendiriannya, mungkin punya makna tersendiri.Yang jelas angka ganjil adalah angka yang disenangi Allah SWT.seperti ditegaskan dalam hadits Nabi:

"Sesunguhnya allah ganjil
menyenangi yang ganjil"

Sarekat Islam sebagai gerakan politik didirikan dengan tujuan untuk membina kerjasama antar sesama anggota, tolong menolong, menciptakan kerukunan antara sesama muslim, menciptakan usaha yang halal dan tidak bertentangan dengan aturan pemerintah baik pusat maupun daerah, menciptakan kehidupan makmur, sejahtera bagi rakyat banyak. Di samping itu ingin meraih kemerdekaan tanah air sebagai sesuatu yang mutlak dan melakukan Islamisasi bagi masyarakat Indonesia.

Sarekat Islam menempatkan agama sebagai dasar berorganisasi, berpolitik, berekonomi dan aspek lain untuk menunjukkan konsistensi partai ini pada Islam, sehingga hal-hal yang bertentangan dengan ajaran Islam harus dijauhkan Lebih-labih jika sudah menyangkut persoalan ideologi, suatu hal yang sangat prinsipil. Oleh karena.itu ketika paham komunis meiakukan infiitrasi ke daiam tubuh partai, mayoritas anggota menoiaknya, meskipun pada akhirnya memperiemah posisi partai di kaiangan para partisipannya sendiri. Inilah yang menjadi kendala besar dalam upaya mempertahankan eksistensi partai yang ketika itu sudah semakin besar.
Sarekat Islam telah berkiprah di dalam menegakkan nilai-nilai nasionalisme luhur bagi bangsa Indonesia, mengembangkan mental keberanian menghadapi perilaku pemerintah yang cendrung sangat memojokkan kaum pribumi dan melakukan terobosanterobosan dengan mencanangkan program kerja real yang membela kepentingan rakyat banyak.

Usaha mulia tidak selalu berjalan mulus, karena dalam hidup ini banyak ditemukan sejumlah kepentingan yang tidak sama. Lebih-lebih jika hal itu merupakan organisasi politik, maka sesuatu yang lumrah jika terjadi konilik kepentingan.Ada yang pro dan ada yang kontra.Sarekat Islam tidak luput dari halhal di atas. Oleh karena itu pemah terjadi pembekuan terhadap organisasi ini, para tokohnya ditahan dan yang paling tragis adalah masuknya ideologi komunis yang sangat berseberangan dengan Islam, disebarksan oleh Sneevliet seorang marxis Belanda di kalangan pengurus partai, sehingga terjadi perpecahan dan membuat partai ini ditinggalkan sebagian para pengikut dan partisipannya..

\section{Daftar Pustaka}

Efendy Bachtiar, Islam dan Negara Transformasi Pemikiran Dan Praktik Politik Islam di Indonesia, Penerbit Paramadina, Jakarta Selatan: Cetakan 1 Oktober, 1998.

Syafii Maarif Ahamad, Islam dan Masalah Kenegaraan, Jakarta: Penerbit PT Pustaka LP3ES, 1996.

Deliar Noer, Gerakan Modern Dalam Islam, Jakarta: LP3ES.

Syadzali, $\mathrm{H}$ Munawir, Islam dan Tata Negara: Ajaran dan Pemikiran. Jakarta Penerbit UI Press Jakarta Edisi Kelima. 